\title{
A Psychiatrist Recalls Life as a Foster Child
}

Francine Cournos, M.D.

T here are many silent foster children who have no adequate way of speaking about their experiences, not even through the dedicated professionals who care for them. As a former foster child myself, it took me years of psychotherapy to find my own voice, and I hope that in writing about my past now I can make a small contribution to our understanding of the emotional needs of children who find themselves in the care of strangers.

M y own troubles began when I was three years old and my father died abruptly of a brain tumor. My older brother was five, and my mother was pregnant with my younger sister. My maternal grandparents moved in to help my M om support and care for us. Two years later, my grandfather died suddenly when he hemorrhaged from a stomach ulcer, and a few months after that my mother was diagnosed with breast cancer. She struggled for six years with her illness, undergoing multiple disfiguring treatments until she succumbed to lung metastases. I was 11 years old. Of the four adults who had raised me, only my grandmother was now left.

Watching so many people die was frightening and confusing. My mother's death was the worst of all. She had been the center of my world, and I missed her terribly. By day, I imitated her stoical response to hardship, carry-

Dr. Cournos is professor of clinical psychiatry at the College of Physicians and Surgeons of Columbia University in N ew York City. Her memoir, City of One, will be published by Norton in May. Address correspondence to her at the New York State Psychiatric Institute, 1051 Riverside Drive, Unit 112, New York, New York 10032. Jeffrey L. Geller, M.D., M.P.H., is editor of this column. ing out my usual routines as if nothing was wrong, but I cried for her every night for more than a year. Still, the most traumatic event of my childhood was my placement into foster care.

Although my aunts and uncles hinted at the possibility, I never believed they would really give me away. My grandmother, who spoke only Yiddish and never learned to read, was becoming increasingly forgetful, which further restricted her already limited ability to negotiate the world. That didn't strike me as a problem, since in many ways I had learned to conduct my own affairs like a miniature adult, including watching over my little sister. I thought we were getting along fine. Besides, I'd grown up with three sets of aunts, uncles, and cousins who lived nearby, so I figured if it came to that, we could always live with them.

But I figured wrong. My family concluded that Grandma was no longer able to care for us, but none of them wanted to take us in. O ne day the uncle who had been designated my legal guardian took my sister and me to some mysterious office where a woman I had never met before announced that we were being placed into foster care. That was in 1958, when I was 13 , and my sister was nine. M y 15-year-old brother had already been placed separately from us, and we never lived with him again.

I was stunned when I heard the news, then wildly angry. I had two contradictory ideas about myself. On the one hand, I was completely helpless, and furious with myself for being impotent. On the other, I was very powerful, totally in control, so much so that I had myself caused everyone in my life to die or abandon me. I threatened to jump off the Empire State Building if they dared go through with the plan. But the threat had no effect.

You have to be processed to become a foster child. There were steps whose sequence and meaning were never clear to me, but I went from this office to that one, and one stranger after another spoke to me. Some of them I liked, some I didn't. But I knew they all were conspiring to banish me, and I didn't trust a single one of them. I was confused, but I was surrounded by the enemy, and there was no one to confide in. I kept silent. At one of the visits I met the couple selected to become my foster parents. I tried to be polite and show a little enthusiasm, but it was a half-hearted and unconvincing act. I didn't want to go anywhere with these strangers. After each step in the process, I was delivered back to my grandmother-a temporary stay of execution.

On the day my family carried out its final act of abandonment, I was taken to the foster agency headquarters for a physical examination. I felt humiliated as I took off my clothes. It reminded me of movies I'd seen of people being sold into slavery, or of horses on the auction block, the customers looking for defects before they decided to put down their money. I certainly felt like damaged goods.

Somehow we passed inspection. My sister and I were ushered to a car, and a mysterious driver and social worker smoothly swept us away from everything familiar. The ride seemed a funeral procession, held in slow motion. We arrived at a gray stone house in the suburbs-Long I sland-where the little private dwellings and sparsely populated streets seemed a world apart from the run-down, crowded, and colorful South Bronx neighborhood I had grown up in.

My foster father, Jack, was a shoe 
salesman with a gravelly voice who kept a low profile while his lively and talkative wife, E rma, stayed home and ran the show. They didn't have any biological offspring, but a year earlier they'd taken in another pair of children, a sister and brother who were then two and four years old. E rma figured we'd be like them, needy children who were looking forward to having new parents to replace the ones we had lost.

But I'd had enough of the cycle of attachment and desertion. Besides, I was a teenager and eager to break away- except that my own family had beaten me to the punch. After two weeks, Erma felt hurt and rejected. The more angrily she demanded I treat her like my mother, the more I recoiled. For a while, I hoped my aunts and uncles would change their minds and come back for me, but the rescue never came.

Soon I fell into a fragmented and unfamiliar state. Toward the outside world I was withdrawn and detached, and on the occasions the foster care agency scheduled visits with my aunts and uncles, they seemed distant relatives I had once met but barely knew. Yet toward myself, and toward my sister, I was overwhelmed by intense feelings of rage and hatred. Since my sister depended on me, I struggled to contain these emotions. I thought constantly about my dead mother, as if doing so was a form of keeping her alive-or perhaps an act of loyalty, proof I would never betray her by acquiring another mother.

E rma spoke repeatedly of her disappointment in me and angrily talked about sending me away. I knew from my brother that foster children often go from place to place and that being physically or sexually abused was common. I could see that E rma was above doing anything of that sort, so it was less frightening to stick it out with her even if she didn't want me. I had forgotten how to love, and it seemed impossible that I would be loved. I was down to the basics: food and shelter. And the familiar was better than the unknown. I was relieved when after about a year $E$ rma decided to let me stay.

During the following two years, I continued to float through time and space in a state of numb, disorganized misery, going through the motions but not really alive. I was aware of my impairment, and ashamed of it. I believed I was peculiar, and had no idea that my feelings were a common response to trauma.

Then, at 16 , this way of being subsided a bit. I became absorbed with the idea that my central problem was a bodily defect, and I focused on one aspect of my anatomy after another, determined to find the specific flaw. I was unaware how strongly I equated losing my parents with damage to myself. At 17 I developed the sensation of a lump in my throat and became convinced that I was about to choke to death. When I tried to fall asleep, I felt short of breath, terrified that once I dozed off, I would stop breathing forever. D octors tried to reassure me there was nothing wrong, but I was convinced otherwise. I had no labels for any of my experiences, so I didn't realize this latest state was a form of anxiety. E very night I stayed awake to the point of exhaustion.

Throughout these years, I remembered my mother's primary lesson: it is essential to function no matter what goes wrong. So I always followed her stoical example, worked after school to help pay my expenses, and graduated from high school as an honor student. By that time, Erma and I had reached a state of truce, even had some appreciation of one another. Still, I could not find my way back to the child who knew the pleasure of being close to other people.

I moved out on my own when I was 19 , attending a tuition-free city college while the foster care agency paid my living expenses. I felt intimate with no one, certain that if I died in my room, it would be days before anyone even noticed. I entered psychotherapy when I was 21. These hours of lowcost treatment continued for many years and were essential to re-establishing myself and becoming a successful wife, mother, friend, and professional. They were also the key to finding the words that gave my experiences coherence and to discovering that I could make myself heard. I fear that many of today's foster children will never be given the resources or the opportunity to do the same. 